\title{
THE POLITICAL ASPECTS \\ FOUND IN WILLIAM SHAKESPEARE'S KING LEAR
}

\author{
By: Ali Fauzi*
}

\begin{abstract}
King Lear explores classical elements like the striking peculiarities of an individual, or the violence of some exceptional character, disregarding the fundamental feelings common to mankind, and ignorant love of humanity. We find Lear, a central character with a particular tragic flaw or hamartia, that is, a character who is led into despair or misery through some sort of error either in himself or in his action; and to hubris which means excessive, self-destructive pride. Lear is led into suffering after which he has a greater understanding of both himself and the world. Lear is an attractive personality with many virtues who has a fairly normal balance of good and evil within him. He is proud and does not know himself and it is a "normal" fault but after it is acted on by events in the play, it brings him down. Evil is let loose in the society of tragedy, and destroys both good and evil characters. Evil unavoidably pollutes and infects the tragic hero himself-Lear. The nature of evil is reflected from the characters of Lear and his first two daughters, Goneril and Regan. Lear undergoes range of tragic life because of his blunder-divides his kingdom and wealth based on parameter of love- which triggers many conflicts and causes many sufferings. His first two daughters, Goneril and Regan, make maneuver to get the inheritance by flattery but Cordelia, Lear's third daughter, represents the struggle of human soul to defend truth and responsibility. To get the kingdom and wealth, she does not want to lie herself and her father by flattery. She just keeps silent or realizes that to love, obey and devote herself to her father is a must. The main ingredient of the play is about human beings and their life. Human life and their problems become subject matter and their basic natures which activate their action and speeches become the object of the play. Human beings and their basic natures are presented by all the characters who act and say based on their roles. Their life and their problems are represented by their life in the kingdom and their social problem happening in it. Since the play tells us the life of the king and the problem of the kingdom, so it exposes all aspects and problems of life in which
\end{abstract}


one of them is the political aspect consisting of dividing kingdom, ruling authoritarian monarchy, doing conspiracy, existing of rivalry, emerging of conflict of interest and treachery.

Key Words: The Political Aspects, William Shakespeare, King Lear

*Ali Fauzi adalah Wakil Ketua III dan Dosen Bahasa Inggris pada Prodi PAI STITMA Tuban

\section{A. INTRODUCTION}

Drama is the work of literature produced by the author resulted from the interpretation of real life in which all social phenomena and human activities become the main ingredient (Wolff, 1981: 1). The author portrays the real life and then proceeds it based on his knowledge and his way of thinking in his mind and then pours it in form of the work. So, the work of the author is the accumulation of all things happening in the real life involving levels of social cooperation and mediation between conception and reception as well as some collective senses which then lead to something called the collective product (Wolff, 1981: 4). As a social product processed in the author's ideas, it has, of course, the relationship between an artistic literary work produced by the author, the author in which he pours his ideas, the world and life which become the material of story and the readers who read, enjoy and find the meaning (Abrams, 1976: 6). It is certain that drama is the work of the author which portrays and reflects the real life based on the real life the author experiences and proceeds through the imagination he has by which he cannot do in other ways. It means that it is the only way the author expresses himself and his experiences of life in the story and another way the readers can experience the world around them through their imagination (Jones, 1968: 3).

As one of Shakespeare's tragedies, King Lear also explores classical elements like the striking peculiarities of an individual, or the violence of some exceptional character, disregarding the fundamental feelings common to mankind, and ignorant love of humanity (Legouis, 1956: 137). In tragedy, we usually find a 
central character with some particular tragic flaw or hamartia, that is, a character is led into death, despair or misery through some sort of error either in himself or in his action; the most often cited flaw is hubris, which means excessive, selfdestructive pride. In this play, Lear is led into suffering after which he has a greater understanding of both himself and the world. Lear, as the major character in the play, is an attractive personality with many virtues, and a fairly normal balance of good and evil within him. It is seen that Lear's tragic flaw is that he is proud and does not know himself. Actually, it is a "normal" fault but after it is acted on by events in the play, it tragically brings him down. Evil is let loose in the society of tragedy, and destroys both good and evil characters. It is unavoidable that evil pollutes and infects the tragic hero himself-Lear. We, at least, recognize the source of evil in the play that is Edmund, Goneril and Regan (Stephen, 1986: 46).

Shakespeare wrote this play in the middle period of his literary career in 1605 - 1606 and worked in experiment with Roman material and created it in which he put his profound vision of the nature of evil and the struggle of human soul (Skimmer, 1977: 656-657). The profound vision of the nature of evil is reflected from the characters of Lear and his first two daughters, Goneril and Regan. Shakespeare presents Lear as a major character who undergoes range of tragic life because of his blunder which triggers many conflicts and causes many sufferings. It is a big blunder and illogical idea for a father and a king to divide his kingdom and wealth based only on love parameter. Knowing this, his first two daughters, Goneril and Regan, make maneuver to get the inheritance by flattery. While, Cordelia, Lear's third daughter, represents the struggle of human soul to defend truth and responsibility. To get the kingdom and wealth, she does not want to lie herself and her father by flattery. Instead, she just keeps silent or she is forced to speak frankly that to love, obey and devote herself to her father is a must and she need not express them through words. That the main ingredient of the play is about human beings and their life is clearly seen. It may be said that human life in the society and their problems becomes subject matter and human beings and their basic natures which activate their action and speeches becomes the 
object of the play. Human beings and their basic natures are presented by all the characters by which they act and say based on their roles. Meanwhile, the subject matter in form of their life and their problems are represented by their life in the kingdom and their social problem happening in it. Since the play tells us the life of the king and the problem of the kingdom, so it exposes all aspects and problems of life in which one of them is the political aspect.

\section{B. THE POLITICAL ASPECTS FOUND IN WILLIAM SHAKESPEARE'S KING LEAR}

Political aspect which becomes the social phenomena happening in the kingdom looks sufficiently dominant in the play because it is not only related to the accountable performance but also related to the perpetuity of kingdom life. Political aspects resulted from the factor of motivation the characters have and the basic natures which activate the characters' action and speech found in the play vary. They among other things are: dividing kingdom, authoritarian monarchy, conspiracy, rivalry, conflict of interest and treachery.

\section{Dividing Kingdom}

The aged King Lear faces quite difficult problem related to his power and authority. His old age forces him to inherit his throne to his daughters to manage. Without asking for others' advices, he decides to divide his kingdom to his three daughters in order to avoid the conflicts among them in the future. In fact, politically, King Lear's intent to divide the kingdom is good but practically it is ominous because what was once whole is now to be divided. It is usual that a kingdom or a family divided for any reason betokens discord, civil war and chaos. Union creates; division destroys (Main, 1962: 3). Logically, to divide the kingdom which in political term is called power sharing (Andi setiono and et als, 2000: 120-121) means to avoid the conflict. But the consequence of this may be worst, for the kingdom becomes three smaller parts and the unfair rivalry to be superior among them becomes stronger. All the more, King Lear's last official act before retirement is to turn his throne into an auction block. He, as an arrogant, stubborn and boastful king, divides his kingdom based on love parameter of his daughters 
to him. He, who should be ripe in wisdom from a lifetime of mistakes, is only ripe in folly. His last mistake is his greatest; he dares to sell what is not for sale - love. "Which of you shall we say doth love us most?/ That we our largest bounty may extend ... (Act I, Scene I). To divide the kingdom is practically bad enough, but to sell it for love is monstrous. King Lear trades land for love. He corrupts the gift of love into a commodity of flattery and materialism, corrupting himself and some of those around him. In short, he commands his daughters to love him, whereas in fact, it is only God who has the right to command love, and King Lear thus far is only a god of follies (Main, 1962: 5).

The unfair decision King Lear declares is susceptible to political lobbying in which it is manifested in form of diplomacy and even flattery. King Lear promises to divide and give the kingdom to his daughters based on their love standard to him. It looks that Cordelia and Regan, King Lear's first and second daughters are talented lobbyists. They use King Lear's weakness to lobby through flattery to get the kingdom. In politics, to lobby others to get prospective power sharing is sometimes very important to do (Andi setiono and et als, 2000: 120121). Therefore, when King Lear asks "Goneril, her eldest-born, to speak first" (Act I, Scene I), Goneril directly flatters him. She says "Sir, I love you more than words can wield the matter; dearer than eye-sight, space and liberty; beyond what can be valued, rich or rare; no less than life, with grace, health, beauty, honor; as much as child ever lov'd, or father found; a love that makes breath poor and speech unable; beyond all manner of so much I love you" (Craig, 1990: 984). King Lear then asks his second daughter, Regan, to speak and she, similar to her elder sister, also flatters her father saying "Sir I am made of the self-same metal that my sister is, and prize me at her worth. In my true heart I find she names my very deed of love; only she comes too short; that I profess myself an enemy to all other joys, which the most precious square of sense possesses; and find I am alone felicitate in your dear highness' love" (Craig, 1990: 984). Nevertheless, when King Lear asks Cordelia, his third daughter, to speak, she just keeps silent although she loves her father. Cordelia does not want to flatter her father to get something, the kingdom, like her sisters do. As for her, to love, to obey and to be 
loyal to parents is a must, and she need not express them in speeches. King Lear forces her to do again but Cordelia just says "nothing, my Lord" (Act I, Scene I). If Cordelia talks, she will be understood as a flatterer; if she remains silent, she will be understood as an ungrateful child without feeling. It seems that any way that love is articulated it is impure. Hence Cordelia must love and be silent. Such is the expression of perfect love in an imperfect world (Main, 1962: 7). Lear is angry with her and says "nothing will come of nothing" (Act I, Scene I). Therefore, King Lear gives a half of his kingdom to Goneril and a half to Regan but gives nothing to Cordelia. He gives all of his possession to Goneril and Regan and they in fact hate him. He gives nothing to Cordelia and she in fact loves him.

\section{Authoritarian Monarchy}

King Lear is an authoritarian monarch. For King Lear, a political leader must not be hesitant and postpone things what he has decided - to divide the kingdom. He must quickly do the decision and brave to take the consequence (Thomas, 1992: 10-11). In doing the decision, however, he never accepts others' ideas but does things according to his will. By the authoritarian power, he becomes tyrannous, stubborn and arrogant individual who leads to the weaknesses of self-control ethically and morally. The characteristics may be detected from his statement "Thou shalt have no other gods before me" (Act II, Scene IV). Lear's other gods are pride, vanity, and wrath; not even Jove and Apollo have a chance with Lear's ego (Main, 1962: 85). The man who plays God must be punished by God. Yet King Lear is Godlike because he is a man who does more than man can do. Lear has the greatest capacity of all for suffering, and such a capacity is a measure of divinity. Kent says that "man's nature cannot carry/The affliction nor the fear," but Lear's nature can because he is superhuman with a divine endurance. Lear is a man who has the power of a transman, of the divine sufferer (Main, 1962: 95). Lear's authoritarianism is seen when he divides his kingdom based on what he will, based on love, materialism and pride. Although Kent protests the decision, he responds it fiercely. All Lear wants must be fulfilled and all he says must be a Constitution. He asks all men to obey and follow his instruction and forces them to respect him. People must struggle and even 
sacrifices their lives for the sake of his authority and hegemony. He must punish those who oppose him or have the different idea with him. Cordelia, who does not want to say love words to Lear, and Kent, who dare to protests Lear for the unjust decision are banished because he thinks that they oppose him although what they do and say are right. It seems that Cordelia's and Kent's persistence in defending their integrities are based on their belief that "honesty is the best policy" (Thomas, 1992: 55). Therefore, they are prepared to accept all the consequence they will take in return.

\section{Conspiracy}

Politically, copious arrogance and self-confidence Lear has is quite disastrous. Lear should be able to play his role and diplomacy as a king and a father brilliantly; at least, he should communicate what he wants and intent to his daughters or else he will be defeated and crushed by those bad passions (Setiono et als, 2000: 120-121). Nevertheless, he does not do it, instead he does the decision only based on his passion of pride and anger. After the folly division of kingdom and the contest of materialism greed, Cordelia departs, knowing that her sisters are wolves and that unfolding time shall unmask them. King Lear, ironically, has banished Cordelia to safety in France while he stays in England with the wolves, Goneril and Regan.

After getting the part of the kingdom and seeing how rashly Lear has treated his beloved Cordelia and the loyal Kent, the two evil sisters immediately plot a conspiracy to rid themselves of their "infirm and choleric" father (Main, 1962: 19). According to the theory of conspiracy, the two opposite poles may meet for the sake of moment collective interests (Suhindriyo, 1992: 181). It means that Goneril and Regan, for the sake of strengthening their each position, agree to meet and to plot a conspiracy to make Lear a common enemy, after the inner dispute in competing to get their father's kingdom. They start to behave and have hostile feelings towards their father. Goneril immediately proceeds to disinherit her father. She turns on the cooling system to freeze out her father, who is no longer of use to her without his power and no longer to be feared without his authority. She exaggerates her father's faults in order to "breed from hence occasions" 
(Main, 1962: 30). By day and night she plots ways to wrong him; she even asks all her servants to disobey and to treat him badly. She always finds the way to wrong him and his hundred knights. She accuses his knights to make noise for the drunk and asks him to decrease the number for the high cost of life. The aged Lear is meddling and childish; he needs patience and love, but Goneril says, "I'll not endure it" (Act I, Scene III). She really needles Lear's tender pride with negligence and disrespect. Like the ungrateful young cuckoo, Goneril is biting off Lear's head. The daughter who once said she loved her father "more than words can wiled the matter" (Act I, Scene I) is now eating her father and her words. Her old mask of flattering love is now off, and it begins to see the true ugliness of inhuman face. Righteously masking her selfishness, Goneril's strategy has shifted from false flattery to true cruelty. Now, the claws within the velvet glove begin to show (Main, 1962: 30).

Having been treated badly by Goneril, Lear intends to go and stay in Regan's palace. Lear asks Kent to go first to Regan's palace bringing a letter telling that her sister has treated him badly and informing that her father will go and stay there. In politics, Kent takes a role as diplomat and does his function to communicate and lobby (Setiono et als, 2000: 145) in Lear's relations with his second daughter, Regan. Then Lear goes after to Regan bringing a hundred of knights. But on arriving there, Lear sees himself that Kent is put in the stock. It indicates the bad sign for the putting of Kent into the stock is purposely to insult Lear. Again, Lear's copious self-confidence to subjugate Regan's strong heart and feeling becomes the factor of his failure and defeat (Setiono et als, 2000: 145). Lear mistakenly thinks Regan will be outraged over Goneril's inhuman, bestial cruelty. He thinks Regan will flay her rival sister over the handsome Edmund, not over old Lear, a common enemy to them both. Apparently, Goneril has arrived there sooner than Lear and she takes Regan's hand to meet Lear. Fachry Ali said that in political practice, one often finds many unpredictable jolts because the logic of interest dominates (Setiono et als, 2000: 125). Lear is shock to know the rivaled sisters meet and behave so intimate that he nearly does not believe it. Regan advises Lear to come back to Goneril's palace and to reduce the number of 
his knights. She also advises that to stay in Goneril's palace, he and his followers must obey the rule and be polite to all. Lear is shock in Regan's attitude but he still forces her to stay in her palace. Regan refuses it and asks Lear to leave the place and shuts the door behind them. Lear is outraged with them and he leads his followers to leave the place for somewhere until they are trapped in the heath amidst the big storm and rain. Indeed, no one could drive a harder bargin with God, man, or the devil than Goneril and Regan. These wicked sisters are so logically right and yet so morally wrong, because they accept completely Lear's original materialistic premise that "Nothing will come of nothing" (Act I, Scene I). Now that Lear has nothing, he logically gets nothing. For the second time, the two sisters plot a conspiracy and succeed to drive Lear away.

\section{Rivalry}

Having divided his kingdom and given a half to Goneril who is married to the duke of Albany and a half to Regan who is married to Cornwall, Lear sees the strong rivalry between them. Yusril Ihza Mahendra in Diplomacy and The Real Politics (Setiono et als, 2000: 98-99) said that theoretically when there are two equal powers, there will be any strong competition which leads to the serious conflicts; for they are prepare to defeat each other. William W. Main stresses that contending rivals without a superior are as divisive as contending elements without the power of attraction, or love (1962: 89). The rumor of "likely wars ... "twixt the Duke of Albany and Cornwall" (Act II, Scene I) reflects the speed with which dissention develops between equal rivals. The equal division of power between Lear's daughters has ironically created war, not peace. Actually, the civil discord between Albany and Cornwall is caused by strife in the form of jealousy and rival power ultimately between Goneril and Regan. Whether between wind and rain or sister and sister, the cause of division is lack of love. Both Goneril and Regan for the sake of their own kingdom compete each other to be the best. They each show of forces, state psywars and declare the threats; they are ready to attack each other.

Aside from rivalry to show superiority of their each kingdom, Goneril and Regan are also having a love affair with Edmund. The dirty and wicked daughters, 
Goneril and Regan have abused love to the highest level of destruction. They cannot be expected to be more faithful to their husbands. After they know Edmund, they start to disrespect their husbands. They soon grow tired and boring with their husbands and give their love to another man. It happens that each of them loves the same man - Edmund - who has long been with them in arranging bad strategy to destruct Lear, Gloucester and Cordelia. Each of them really competes to win Edmund's love through the shameful flattery and other ways. The sharing of interests and of positive feelings which nurtured friendship are now transmitted by sex into the capacity for adult love (London, 1975: 428). Indeed, falling in love is sometimes a painful experience because they feel a terrible longing for the loved person, a passionate desire to be with him all the time, to share everything with him, to immerse their whole existence with him (Moskowitz and Arthur, 1969: 56). To Goneril, the honest, moral Albany is a mild, cowardly fool, and the cool, the treacherous Edmund is the ideal of virtuous manhood. Goneril says “O, the difference of man and man!”(Act IV, Scene II), unable to tell which man is angel and which is devil. Regan, because of his love to Edmund, insists him to clarify "Now sweet lord, tell me-but truly-but then speak the truth, do you not love my sister?"(Act V, Scene I). But Edmund, with his instinct of a gigolo, is supremely pragmatic in his love for the wicked sisters. He flatters Goneril and Regan that he loves them more. When he is not with the woman he loves, he pragmatically loves the woman he is with. He says "In honour'd love, I love you" (Act V, Scene II), when he meets each of them. All Edmund cares about is marrying the survivor, for either Goneril or Regan could be queen and thereby make Edmund king. After Cornwall, her husband dies, Regan determines to marry Edmund. But Goneril, for being jealous, takes an act to poisons Regan. Knowing this, Albany then puts Goneril in the prison where she then dies for committing suicide resulted from being frustrated. In the end, the rivalry of the dirty lives and the decayed souls of the sisters Goneril and Regan come to a violent, self-destructive end; it sends them to death and these demonic persons gain nothing in their losses (Main, 1962: 203). 
Obviously, one finds two rivalries in the play. The first is internal rivalry between Goneril and Regan to show the superiority of their each kingdom in England and to win Edmund's love in their palaces. The second is external rivalry between France manifested by Cordelia and England represented by Goneril and Regan. It must be kept in mind that King Lear is a tragic play written in legendBritish legend-because Shakespeare combined historical values and old stories (Legouise, 1956: 127). The war between France, a kingdom where Cordelia must defend and allied army of Goneril's and Regan's from England reflects historical realism. Historically, one finds family relationship between France and English noblemen. However, the two countries which have genetic relationship among the noblemen have often strong rivalry and always compete to be more superior than the other so that it often causes the war between them.

In this reason, historical element is reflected from the major character, Lear who becomes the symbol of courage and heroism of the king of England. Meanwhile, the legend element is detected from the popularity of this drama among the people of England so that it indeed becomes the great mythology. From the aspect of story, the hero sometimes represents the idol character of the society who comes up as the manifestation of fact of life and has the sides related to the public as the source of representation (Elizabeth and Tom Burns, 1973: 280). Shakespeare presents Lear as a protagonist and legend hero who historically reflects individual as well as social-moral determinants causing historical collision in form of conflict with his first two daughters, Goneril and Regan (Elizabeth and Tom Burns, 1973: 281). The internal conflicts which happen among the family in English kingdom end because both sisters agree to ally themselves to face their common enemy, Cordelia's army as the representative of France kingdom who comes to attack them. The conflict between England and France becomes the basic rule of developing the historical collision causing serious destruction of life between them but it then brings enlightenment of life with the coming home of Cordelia to save her father and to show the truth. So, the long history telling the war between France and England because of their rivalry has happened since the old time and become the everlasting story. 


\section{Conflict of Interest}

In politics, one does not find black or white but all are gray. The term habitually used is that "there is no eternal friend and rival but one phrase that is conflict of interest" (Setiono et als, 2000: 191). Two kingdoms which are formerly enemies may then become a friend, on the contrary, those which firstly a friend may become enemy they must destroy. This happens to Goneril and Regan. They, who competed to show their superiority of their kingdom and to win Edmund's love, now agree to cooperate and to meet collective understanding. For the sake of their both interests, they, who first each hostiled strongly, all of sudden become a firmly friend to destroy France army led by Cordelia, their common enemy. The peak of all, they agree to put their love rivalry aside and to promote Edmund as the commander-in-chief to face Cordelia who comes to save her father and to take revenge against her sisters. "Combine together 'gainst the enemy; for these domestic and particular broils are not the question here" Goneril says. Regan responds it warmly saying "Sister, you'll go with us? 'tis most convenient; pray you, go with us." They really work together for one thing - to destruct Cordelia. But the coming of Cordelia has, at least, made Lear and her whole again after being torn apart by Goneril and Regan. A common enemy can unite two enemies. The brave Edmund fights fiercely against Cordelia's and manages to defeat hers. He succeeds to arrest her and puts her death. The unite of the two kingdoms proves the world that "union creates; division destroys" (Main, 1962: 3).

Edmund, who is the figure joining the major plot represented by the family of Lear and sub-plot represented by the family of Gloucester, has also conflict of interest concerning with the dispute between Goneril and Regan. He knows that they are enamored of him and that he takes the most important role in the shameful scandal. To fulfill his conflict of interest, Edmund must, according to Eep Saefulloh Fatah "set double strategies; the strategy of power sharing and target getting" (Setiono et als, 2000: 255-256). Machiavelli adds that ace holder will gain big fortune if he will choose between a fox and a lion and he needs equip himself with the art of power and cunning (Thomas, 1992: 61). Luckily, Edmund has them all. He, with his instinct of a gigolo, is supremely pragmatic in his love 
for the wicked sisters. He sets the net to get power sharing by flattering Goneril and Regan that he loves them more. When he is not with the woman he loves, he pragmatically loves the woman he is with. He says "In honour'd love, I love you" (Act V, Scene II), when he meets each of them. All Edmund cares about is marrying the survivor, for either Goneril or Regan could be queen and thereby make Edmund king. It is his target getting. To make the road to success, he instigates the brave servant of Goneril to kill Cornwall, Regan's husband, on his sin for stabbing Gloucester's eyes. After Cornwall dies, Regan declares to marry Edmund but Goneril poisons her for being jealous of Edmund. Albany, who knows the crime of Goneril, then sends her to the jail where she soon commits suicide for being frustration. It is ordained that Edmund cannot reach his expectation to be the king of England.

\section{Treachery}

Politically, treachery often happens among the practitioners to get their objectives. In Arbi Sanit's opinion “Treachery is the elder brother of deception and it is the part of political art" (Setiono et als, 2000: 209). Usually, the doers deceive the rivals first, then they execute them through the treachery. Goneril and Regan deceive their father through their flattery speeches to get the kingdom that they love him more than anything else in the world. But short time after inheriting half of her father's kingdom, they betray their father's goodness. Similarly Edmund also deceives his father and betrays his brother. He shows his father a forged letter informing that Edgar has a plan to overthrow him and Cornwall. Whereas, it is Edmund's handwriting; it is he himself who writes the letter. Knowing this, Gloucester and Cornwall are furious over Edgar and threats him to put death. Edmund treacherously pretends to help his panicked brother escape from the alleged revengeful threats of Gloucester and Cornwall; Edgar supposedly has rebelled against his father and the duke. Gloucester then gives Edmund his land and banishes Edgar in nothingness. As soon as Edmund has received his father to get the land, he then has a plan to destroy his father to replace his position. He deceives Cornwall and tells a lie that Gloucester will overthrow him. It makes Cornwall angry with Gloucester and he punishes him by stabbing his 
eyes. Cornwall and Regan banish Gloucester in his blindness. As usual, Edmund uses one person to remove another. He uses Gloucester to remove Edgar; now Cornwall removes Gloucester from Edmund's path to power and make Edmund Earl of Gloucester. For Edmund, the way to success is now in front of the eyes; his dreams will really come true. Edmund also deceives and betrays Goneril and Regan, the daughters who have deceived and betrayed their father and their husbands. Edmund knows that both the sisters fall in love with him. With his instinct of a gigolo, he is supremely pragmatic in his love for the wicked sisters. When he is not with the woman he loves, he pragmatically loves the woman he is with. All Edmund cares about is marrying the survivor, for either Goneril or Regan could be queen and thereby make Edmund king.

\section{CONCLUSION}

There are many political aspects found in the play. The first is to divide the kingdom. Politically, King Lear's intent to divide the kingdom is good. But if he divides it through the wrong way, it is ominous because what was once whole is now to be divided. To divide the kingdom in political term is also called power sharing in which it is meant to avoid the conflict among children in the future. But Lear divides his kingdom based on love parameter of his daughters to him. The unfair decision King Lear declares is susceptible to political lobbying in which it is manifested in form of flattery Goneril and Regan do.

The second is authoritarian monarch. King Lear is an authoritarian monarch. As a political leader, King Lear must not be hesitant and postpone things what he has decided. In deciding something, he never accepts others' ideas but does it according to his will. By the authoritarian power, he becomes a tyrannous individual who leads to the weaknesses of self-control ethically and morally. Lear's authoritarianism is seen when he divides his kingdom based on what he will, based on love, materialism and pride. Although Kent protests the decision, he responds it fiercely. He punishes those who oppose him or have the different idea with him. 
The third is conspiracy. Politically, to avoid or at least to minimize the conspiracy, Lear should be able to play his role and diplomacy as a king and a father brilliantly but he does not do it, instead he does the decision only based on his passion of pride and anger. After getting the part of the kingdom, the two evil sisters, Goneril and Regan, immediately plot a conspiracy to wrong him. They start to behave and have hostile feelings towards their father. Next, they plot a conspiracy to banish their father. Lear is outraged with them and he leads his followers to leave the palace for somewhere until they are trapped in the heath amidst the big storm and rain.

The fourth is rivalry. Having divided his kingdom and given a half to Goneril and a half to Regan, Lear sees the strong rivalry between them. Theoretically when there are two equal powers, there will be any strong competition which leads to the serious conflicts; for they are prepared to defeat each other. Both Goneril and Regan for the sake of their own kingdom compete each other to be the best. Aside from rivalry to show superiority of their each kingdom, Goneril and Regan are also having a love affair with Edmund. Each of them really competes to win Edmund's love through the shameful flattery and other ways. There are two rivalries in the play. The first is internal rivalry between Goneril and Regan. The second is external rivalry between France, Cordelia and England, Goneril and Regan. The war between France, a kingdom where Cordelia must defend and allied army of Goneril's and Regan's from England reflects historical realism. Cordelia lands in England to attack her sisters and to save her father.

The fifth is conflict of interest. In politics, one does not find black or white but all are gray. Two kingdoms which are formerly enemies may then become a friend, and vise versa. Goneril and Regan, who competed to show their superiority of their kingdom and to win Edmund's love, now agree to cooperate and to destroy France army led by Cordelia, their common enemy. Even, they promote Edmund as the commander-in-chief to face Cordelia who comes to save her father and to take revenge against her sisters. The brave Edmund fights fiercely against Cordelia's and manages to defeat hers. Edmund has also conflict of interest 
concerning with the dispute between Goneril and Regan. He knows that they are enamored of him and that he takes the most important role in the shameful scandal. To fulfill his conflict of interest, Edmund must set double strategies; the strategy of power sharing and target getting. He sets the net to get power sharing by flattering them When he is not with the woman he loves, he pragmatically loves the woman he is with for either Goneril or Regan could be queen and thereby make Edmund king-his target. He also instigates the brave servant of Goneril to kill Cornwall on his sin for stabbing Gloucester's eyes. Goneril poisons Regan for being jealous of him. Albany then sends Goneril to the jail where she soon commits suicide for being frustration.

The sixth is treachery. In politics, treachery often happens among the practitioners to get their objectives. Usually, the doers deceive the rivals first, then they execute them through the treachery. Goneril and Regan deceive their father through their flattery speeches to get the kingdom. But short time after inheriting half of her father's kingdom, they betray him. Similarly Edmund also deceives his father and betrays his brother. For believing in Edmund's lie, Gloucester gives him his land and banishes Edgar in nothingness. As soon as Edmund has deceived his father to get the land, he then has a plan to destroy his father to replace his position. He deceives Cornwall and tells a lie that Gloucester will overthrow him. Again, Cornwall is angry with Gloucester and he punishes him by stabbing his eyes. Edmund then becomes the Earl. He also deceives and betrays Goneril and Regan to get the kingdom of England. With his instinct of a gigolo, he pragmatically loves the woman he is with when he is not with the woman he loves. All Edmund thinks about is to be the king of England.

\section{REFERENCES}

Abrams, MH. 1976. A Glossary of Literary Terms. Sydney: Holt, Rinehart and Winston.

Craig, W.J. 1990. The Complete Works of William Shakespeare. London: Henry Pordes. 
Elizabeth and Tom Burns (Ed). 1973. Sociology of Literature and Drama. Middlesex, England: Penguin Books Inc.

Hornby, AS. 1974. Oxford Advance Learner's Dictionary of Current English. London: Oxfor University Press.

Jones, Jr. Edward. H. 1968. Outline of Literature. New York: The Macmillan Company.

London, Perry. 1975. Beginning Psychology. London, England: The Dorshey Press.

Legouise, Emile. 1956. A Short History of English Literature. Great Britain: Oxford at the Clarendon Press.

Moskowitz, Merle J. and Arthur R. Orgel. 1969. General Psychology. Boston: Houghton Mifflin, Co.

Main, William W. 1962. The Tragedy of King Lear. New York: The Odyssey Press Inc.

Suhindriyo. 1992. Biografi Singkat Presiden-Presiden Amerika Serikat. Yogyakarta: Yayasan Pustaka Nusatama.

Setiono, Andi. (Ed). 2000. Tragedi Megawati: Revisi Politik Massa di Indonesia. Yogyakarta: Tarawang.

Stephen, Martin. 1986. An Introductory Guide to English Literature. London: Longman York Press.

Skimmer. (Ed). 1977. The Encyclopedia Americana. New York: American Book Company.

Thomas, Keith. (Ed). 1992. Machiavelli: Dilema Kekuasaan dan Moralitas. Jakarta: Pustaka Utama Grafiti.

Wolff, Janet. 1981. The Social Production of Art. USA: St. Martin's Press. 